\title{
Entrepreneurship education revisited: perceived entrepreneurial role models increase perceived behavioural control
}

\author{
Katharina Fellnhofer \\ Lappeenranta University of Technology, \\ LUT School of Business and Management, \\ P.O. Box 20, 53851 Lappeenranta, Finland \\ Email: katharina.fellnhofer@lut.fi
}

\begin{abstract}
Relying on Bandura's (1986) social learning theory, Ajzen's (1988) theory of planned behaviour (TPB), and Dyer's (1994) model of entrepreneurial careers, this study aims to highlight the potential of entrepreneurial role models to entrepreneurship education. The results suggest that entrepreneurial courses would greatly benefit from real-life experiences, either positive or negative. The results of regression analysis based on 426 individuals, primarily from Austria, Finland, and Greece, show that role models increase learners' entrepreneurial perceived behaviour control (PBC) by increasing their self-efficacy. This study can inform the research and business communities and governments about the importance of integrating entrepreneurs into education to stimulate entrepreneurial PBC. This study is the first of its kind using its approach, and its results warrant more in-depth studies of storytelling by entrepreneurial role models in the context of multimedia entrepreneurship education.
\end{abstract}

Keywords: entrepreneurship education; success stories; failure stories; role model; PBC; perceived behaviour control; TPB; theory of planned behaviour; social learning theory; entrepreneurial self-efficacy.

Reference to this paper should be made as follows: Fellnhofer, K. (2017) 'Entrepreneurship education revisited: perceived entrepreneurial role models increase perceived behavioural control', Int. J. Learning and Change, Vol. 9, No. 3, pp.260-283.

Biographical notes: As an Erwin-Schrödinger-Fellow, Katharina Fellnhofer is a Visiting Researcher at the Lappeenranta University of Technology, Finland. She holds a $\mathrm{PhD}$ in Social and Economic Sciences from the University of Innsbruck, Austria. In addition, she is an entrepreneur of an Austrian small- to medium-sized company which is engaged in interdisciplinary European research and innovation projects.

\section{Introduction}

Entrepreneurship education is a crucial element of economic policies aimed at creating employment and growth (Matlay and Matlay, 2006), which has resulted in serious debate about its effects (e.g., Gartner and Vesper, 1994; Henry et al., 2005; Weaver et al., 2006; Dickson et al., 2008; Callagher et al., 2015). A meta-analysis comprising 42 independent 
samples found that entrepreneurship education was beneficial, presenting a relatively high average effect size (Martin et al., 2013). The analysis included seven studies that measured perceived behaviour control ( $\mathrm{PBC})$ as an outcome variable, which was assessed, for instance, by the number of businesses founded (Kolvereid, 1996; Souitaris et al., 2007). Generally, most studies of effects are descriptive and lack a rigorous theoretical framework to evaluate entrepreneurship education initiatives. Several studies have explicitly noted this weakness in the context of effectively measuring entrepreneurship education (e.g., Weaver et al., 2006) and in the context of lack of innovative techniques for increasing entrepreneurial behaviour (e.g., Kuratko, 2005; Chen, 2014).

Although 19 studies in the literature have applied the theory of planned behaviour (TPB), originally conceptualised by Ajzen (1988), only a few have used entrepreneurial behaviour as a dependent variable (e.g., Souitaris et al., 2007). In addition, existing research has neglected the effects of entrepreneurial education and entrepreneurial role models as facilitators of entrepreneurial career choices or behaviour (Muofhe and du Toit, 2011). Therefore, to help fill this gap, the present study aimed to investigate the effects of role models on entrepreneurial PBC in both outside and in the context of entrepreneurship education. To ensure the generalisability and validity of the applied mechanisms and techniques, the study built on three theories: TPB (Ajzen, 1988), social learning theory (Bandura, 1986), and Dyer's (1994) model of entrepreneurial careers (Glaub et al., 2014).

The validity of TPB has been stressed in previous studies, including those by Sheppard et al. (1988), Krueger et al. (2000), Krueger (2009), and Schlaegel and Koenig (2014). According to Liñán et al. (2011), perceptions favouring an action - in this case becoming an entrepreneur - which is defined as PBC, can be influenced in the context of entrepreneurship education. In particular, a central aim of most entrepreneurship programs is to create awareness of entrepreneurial activities (von Graevenitz et al., 2010) or necessary entrepreneurial knowledge and skills (Oosterbeek et al., 2010). In this regard, social learning theory (Bandura, 1986, 1977) provides the fundamentals of how entrepreneurship education can affect entrepreneurial behaviour. Bandura's (1977) theory emphasises the importance of observing others to discover new knowledge and paths by observational learning. Finally, the present study also builds on Dyer's (1994) model of entrepreneurial career choices, which stresses the positive contribution of role models. One such contribution, perceived self-efficacy, is a central variable in the framework proposed by the present study.

In the context of self-efficacy also entrepreneurial experience via knowledge plays a role. For instance, Li et al. (2015) stress that prior knowledge significantly and indirectly affects entrepreneurial opportunity recognition via its impact on entrepreneurial alertness. Furthermore, a longitudinal survey on behalf of Roxas (2014) comprising data of 245 students in a Philippine University observes the direct and indirect effects of knowledge on an individual's entrepreneurial intentions increased via an entrepreneurship education program which highlights the importance of emerging knowledge to ones' self-confidence and an attitudinal tendency toward entrepreneurship. Additionally, Malebana's (2017) findings stress significant associations between the knowledge of entrepreneurial support and entrepreneurial intention among others. This result derived from a sample consisting of 355 students from two African universities. Thus, role models are expected to accelerate ones' entrepreneurial knowledge and experience. 
In general, entrepreneurial experience and knowledge are based on entrepreneurial learning which has established to a topic of substantial interest (McKeon et al., 2004). Entrepreneurial learning tends to be practitioners related. It can be multifaceted extending from courses to more structured degree programs. For instance, McKeon et al. (2004) discuss an example how multinational enterprises provide a crucial source of learning for small to medium-sized enterprise entrepreneurs. Thus, following this vital learning tree, existing entrepreneurs could act as role models and thus a source of entrepreneurial learning for future entrepreneurs. However up to now, in particular, research dedicated toward multimedia entrepreneurial learning of nascent entrepreneurs is limited. With the objective of extending our understanding in this discipline, this investigation inspects role models as a source of learning for potential entrepreneurs. Role models show potential to build bridges for innovative entrepreneurial activities such as consultants in technology transfer (Bessant and Rush, 1995) or to implement a mechanism for strengthening enterprises (Ianioglo and Polajeva, 2017) in our changing society (Drucker, 2011).

Entrepreneurial behaviour as an outcome of entrepreneurship education warrants more intensive research attention (Pittaway and Cope, 2007; Bird et al., 2012). The present study assessed the effects of role models in entrepreneurship education by embedding multimedia narratives of entrepreneurs discussing their successes and failures in a web-based questionnaire. The results of regression analysis are based on 426 individuals, primarily from Austria, Finland, and Greece, show that role models increase learners' entrepreneurial perceived behaviour control (PBC) by increasing their self-efficacy.

The paper is structured as follows. Section 2 discusses the study's theoretical framework. Section 3 discusses its hypotheses regarding the effects of entrepreneurship education on entrepreneurial PBC. Section 4 discusses the study's methodology, and Section 5 presents the results of its regression analyses. Section 6 discusses the study's conclusions and practical implications, including its limitations, and suggests further research.

\section{Theoretical framework}

Entrepreneurship education is "any pedagogical program or process of education for entrepreneurial attitudes and skills" (Fayolle et al., 2006, p.702). Within this framework, there are various types of objectives for various groups targeted by entrepreneurship education (McMullan and Long, 1987; Gorman and Hanlon, 1997; Bridge et al., 1998; Liñán, 2004), which focuses mainly on increasing awareness of entrepreneurship, but which should also prepare potential entrepreneurs for founding new ventures. Entrepreneurship programs that seek to do this disseminate entrepreneurial knowledge and skills to help potential entrepreneurs start businesses (e.g., Liñán, 2004; Boyles, 2012) or motivate their entrepreneurial talents (Glaub et al., 2014) via entrepreneurial coaching (Rasmussen and Sorheim, 2006). Other entrepreneurship education studies have focused on programs that increase confidence related to performing various entrepreneurial tasks (e.g., Chen et al., 2001).

Prior studies have indicated that multimedia communication by entrepreneurial role models that aim to facilitate entrepreneurial behaviour have great potential to present entrepreneurism as an attractive career path (EC, 2013). In addition, prior research has indicated that investigating this type of education requires theoretical fundamentals, 
including TPB (e.g., Robinson and Sexton, 1994; Kolvereid and Moen, 1997; Marques et al., 2012; Rauch and Hulsink, 2015) and social learning theory (Bandura, 1986) with respect to prior research linked to gender-related issues (e.g., Anna et al., 2000), entrepreneurial identity (e.g., Matlay and Harmeling, 2011) or role models (e.g., Chlosta et al., 2012). These approaches make up a wide-ranging portfolio of diverse education techniques (Kuratko, 2005; Mustar, 2009; Neck and Greene, 2011). Entrepreneurship courses not only facilitate acquiring entrepreneurial skills, but they also aim to inspire, motivate, and positively affect perceptions of entrepreneurship; in other words, to stimulate entrepreneurial PBC.

\subsection{Theory of planned behaviour}

Overall, the concept of TPB has been applied across different disciplines. For instance, TPB was used for predicting the intention to marriage (Shahrabadi et al., 2017), cycle commuting intention (Lois et al., 2015), job seekers' intention (Tsang et al., 2015), intention of females' breastfeeding in areas of economic hardship (McMillan et al., 2008) or farmers' decisions to diversify or specialise their businesses (Hansson et al., 2012). To be more precise, Ajzen's TPB (1988) proposes that (entrepreneurial) behaviour is best predicted by (entrepreneurial) intentions to perform the anticipated (entrepreneurial) behaviour one day (Ajzen, 1988, p.132) and that such intentions are formed by attitudes, subjective norms (SN), and PBC. Attitudes are defined by perceptions that a particular (entrepreneurial) behaviour will lead to an expected result. SNs are reflected by the perceptions of others in the social environment, including family, friends, and role models regarding a particular behaviour. PBC presents perceptions concerning entrepreneurial behaviour as self-controllable. Several studies have applied TPB to evaluate both the likelihood of becoming an entrepreneur (Krueger et al., 2000; Peterman and Kennedy, 2003; Liñán and Chen, 2009; Kautonen et al., 2013) and the effects of entrepreneurship education (Athayde, 2009; Mwasalwiba, 2010; Liñán et al., 2011; Ferreira and Fernandes, 2012; Schlaegel and Koenig, 2014). Therefore, TPB provides a profound, well-validated framework for assessing in detail the effects of entrepreneurial role models on entrepreneurial behaviour. However, TPB alone represents an insufficient condition for improving entrepreneurial culture and engagement. Another important aspect is entrepreneurial socialisation.

\subsection{Social learning theory}

Another theoretical approach highlights the role of entrepreneurial socialisation. Social learning theory (Bandura, 1986, 1977) is conceptually narrower than TPB and thus provides a basis for how entrepreneurship education affects entrepreneurial PBC by influencing the motivation and capability to engage in specific entrepreneurial activities. Bandura's (1977) theory emphasises observing others' emotions, attitudes, and behaviours. In short, learning by observing the environment enables discovering new knowledge and paths. In this framework, the multi-dimensional concept of entrepreneurial self-efficacy is a strong tool for understanding the driving force for creativity (Tierney and Farmer, 2002), which has been discussed in the context of entrepreneurship education (e.g., Lerner et al., 1997; Klapper, 2014). 


\subsection{Entrepreneurial career model}

Dyer's (1994) model of entrepreneurial careers explains the components of education central to preparing individuals for a successful entrepreneurial career, including career selection, socialisation, orientation, and development (Gibb, 1994). Based on this model, entrepreneurial career choices, among others, can be influenced by role models. In the framework of the present study, a central variable was perceived self-efficacy, which affects individuals' expectations regarding future outcomes that influence career goals. Several qualitative studies have investigated the relationship between education and career choices linked to entrepreneurship (e.g., Albert et al., 1991; Lerner et al., 1997; Dickson et al., 2008; Solomon and Matlay, 2008; Stokes and Wilson, 2010).

In short, TPB, social learning theory and entrepreneurial career model are important underlying theoretical concepts that role models, enhanced with their success and failure stories (communicated by multimedia), can facilitate entrepreneurial self-efficacy via PBC in entrepreneurship education. While (entrepreneurial) perceived behaviour appears to be an adequate predictor according to Ajzen's TPB (1988), Bandura's (1977) theory emphasises observing others effect (entrepreneurial) self-efficacy which is also in line with Dyer's (1994) model of entrepreneurial careers stressing that education - via observing and learning from role models - can boost one's entrepreneurial knowledge and experience to increase PBC which appears to be crucial when preparing individuals for a successful entrepreneurial career.

\section{Hypotheses}

Entrepreneurship education shows great potential to boost entrepreneurial PBC by persuading students to establish businesses (Fayolle et al., 2006). The present study developed an integrative model that provides a basis for a measuring instrument that builds on Ajzen's (1988) theory and also integrates elements of other theories, including social learning theory (Bandura, 1986, 1977), and career models, including Dyer's (1994) model of entrepreneurial careers. Since these models are associated with entrepreneurial career choices and appear to be interrelated, an integrative research model was developed for this study. Figure 1 depicts the integrative research model, which does not explicitly include SN and attitudes, although they reflect crucial elements of the original TPB. To stress the underestimated potential of role models in entrepreneurship education, the study defined 'SN' as role models and 'attitude' as entrepreneurial self-efficacy that represents antecedents of PBC. In other words, the study assumed that role models, enhanced with their success and failure stories (communicated by multimedia), facilitated entrepreneurial self-efficacy via PBC in entrepreneurship education. The hypotheses underlying this assumption are discussed next.

\subsection{Success and failure stories}

Although the notion of the entrepreneurial role model was first introduced by Gibson (2004) as a cognitive construction to similar identities who are attractive to imitate, so far its effects on and relationship to entrepreneurship education have been not studied. According to Lockwood (2006), role models are persons who present an example of the desired success and thus a template of the behaviours required to be successful. 
Some studies (e.g., Bosma et al., 2012; Chlosta et al., 2012) have shown that parents who are entrepreneurs act as entrepreneurial role models and increase entrepreneurship behaviour in their children by the socialisation process in the family setting (Bandura, 1977). Entrepreneurial role models can also be outside the family. Kuckertz (2013) and others (Aronson, 2004; Souitaris et al., 2007; Carver et al., 2010) have underlined the educational advantages of observing such individuals. Thus, in line with the recommendations of Rahman and Day (2014) on informal and formal learning, role models who tell entrepreneurial stories would strengthen the traits and personalities of potential entrepreneurs. Within this narrative context, what the entrepreneurs did in certain situations is of interest (Harmeling and Sarasvathy, 2013) and shapes perceptions of them as role models. In principle, biographic assignments (Verduyn and Jansen, 2005) have already been applied as a pedagogical technique in entrepreneurship education. Overall, sharing professional stories facilitates the learning process in multiple ways. Practical knowledge is constructed through understanding and interpretation, and as a consequence, a bridge is built between theory and practice (Ritchie and Wilson, 2000; Dewhurst and Lamb, 2005). Because storytelling develops reflective and explanatory thinking, this educational method appears to be useful for constructing (entrepreneurial) knowledge, identity, and skills in both the listeners and tellers (Schatz-Oppenheimer and Dvir, 2014). In short, in entrepreneurship education, both the success and failure stories of entrepreneurial role models show great potential for inspiring one's perceptions of role models. Thus, we predicted the following.

HIa: Entrepreneurial success stories influence one's perceptions of role models.

H1b: Entrepreneurial failure stories influence one's perceptions of role models.

Figure 1 Proposed research model

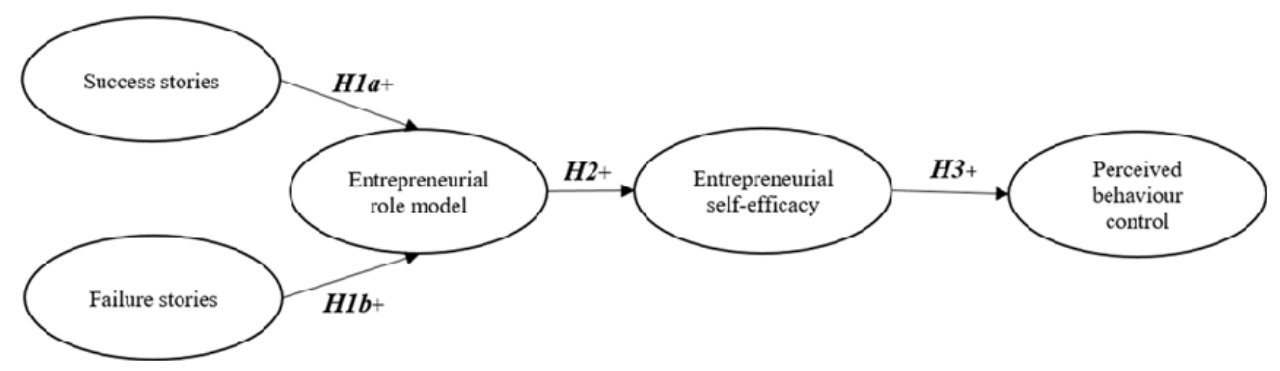

\subsection{Entrepreneurial role models}

According to some studies (Aldrich et al., 1998; Hout and Rosen, 1999), by serving as role models, entrepreneurial parents, family members, or friends influence career choices and self-efficacy. General self-efficacy relates to "one's estimate of one's overall ability to perform successfully in a wide variety of achievement situations, or to how confident one is that she or he can perform effectively across different tasks and situations" (Chen et al., 2001, p.63). In this context, several studies, in particular, have found that self-efficacy increases entrepreneurial intentions (e.g., Zhao et al., 2005; Wilson et al., 2007; Pihie and Bagheri, 2013) and motivations to found a business (e.g., Chen et al., 1998; Rauch and Frese, 2007; Lin and Si, 2014). Both researchers and educators have demonstrated that perceived self-efficacy influences behaviour, and entrepreneurial self- 
efficacy plays a critical role in motivating individuals to become entrepreneurs. Fundamentally, Bandura (1986) concluded in his empirical study on entrepreneurial education and self-efficacy that entrepreneurial education positively affects perceptions of one's ability to become an entrepreneur. In addition, Fayolle et al. (2006) specified that entrepreneurial intentions are more solid when self-efficacy is increased by the attentions of entrepreneurial role models. In their multiple regression analyses, Quimby and Santis (2006) found that levels of self-efficacy and role-model inspiration differed across various career paths. In line with these studies, the present study expected that exposure to entrepreneurial role models within the framework of entrepreneurship education would increase confidence in the overall ability to follow an entrepreneurial career path. Overall, results of the present study were expected to be in line those of Rahman and Day (2014), who argued that role-model involvement in entrepreneurship education increased motivation to choose an entrepreneurial career. In this regard, the following hypothesis was shaped.

H2: Role models influence one's entrepreneurial self-efficacy.

\subsection{Entrepreneurial perceived behaviour control}

Both researchers and educators have demonstrated that perceived self-efficacy influences behaviour. Entrepreneurial self-efficacy plays a critical role in motivating individuals to become entrepreneurs. Fundamentally, Bandura (1986) concluded in his empirical study on entrepreneurial education and self-efficacy that entrepreneurial education positively affects one's perceptions of his or her ability to become an entrepreneur. However, until now only a few studies have examined the antecedents of entrepreneurial intentions and nascent $\mathrm{PBC}$ as career choices in entrepreneurship (education) research (e.g., Zhao et al., 2005; Barbosa et al., 2007; McGee et al., 2009; Zellweger et al., 2011). Entrepreneurial intentions have been used as self-predictions of expected behaviour (Ajzen, 1991; Ajzen and Fishbein, 1977). In short, once intentions are developed, real behaviour can be expected.

Several empirical studies have focused on nascent entrepreneurship (e.g., Carter et al., 2003; Davidsson and Honig, 2003; Arenius and Minniti, 2005). However, only a few have included entrepreneurial self-efficacy as an explanatory variable of nascent behaviour (McGee et al., 2009). Nevertheless, the theory linking entrepreneurial selfefficacy and entrepreneurial nascent behaviour is rather straightforward. Because nascent behaviour follows intentions, influences that encourage intention - including entrepreneurial self-efficacy - would likewise explain nascent entrepreneurial behaviour. In this regard, as research shows that self-efficacy plays a significant role in determining career choices (Chen et al., 2004; Pihie and Bagheri, 2013; Saeed et al., 2015), selfefficacy reflects an appropriate construct for explaining behaviour. Furthermore, PBC can be modified by providing entrepreneurial perspectives and knowledge regarding entrepreneurial experiences (Van Gelderen et al., 2008). In short, entrepreneurship education with storytelling shows great potential to boost PBC by enhancing one's perspective about his or her capability to engage in entrepreneurial activities. In line with this argumentation, the following hypothesis was proposed.

H3: Entrepreneurial self-efficacy increases $P B C$. 
The model in the present study undertakes a causal chain from entrepreneurial stories to role models to the intervening concepts, including self-efficacy, and finally to the central result of entrepreneurship education: entrepreneurial PBC (Figure 1). In other words, an individual's perceptions and $\mathrm{PBC}$ will be altered positively by observing role models via multimedia entrepreneurship education, and this modification in perceptions will significantly increase entrepreneurial PBC.

\section{Methodology}

\subsection{Research design}

Data for the present study were collected in Austria, Finland, and Greece from FebruaryJuly, 2016. The participants volunteered to participate in an entrepreneurship education course outside the curriculum and were free to choose which story from which entrepreneur they would watch. The measurement instrument was a questionnaire, which participants completed both before and after viewing the entrepreneurial story from the role model. The study included only pairs of completed questionnaires. Although the study used an ex-ante-ex-post-research design, it used only the results of the postassessment, after participants had watched an entrepreneurial role model tell a story online, which was an entrepreneurship education activity outside the curriculum and was designed especially for this study.

\subsection{Sample}

The study's research sample included 160 individuals in Austria, 128 in Finland, 103 in Greece, and 35 participants in other locations, for a total of 426 participants, $37.32 \%$ of whom were female and $62.68 \%$ of whom were male. The course consisted of seven entrepreneurial stories told by entrepreneurs from Austria, Finland, and Spain who had founded small and medium-sized companies in Austria, Finland, Spain, Italy, Germany, Switzerland, the United States of America, and Australia. The business sectors involved included venture capital (the story watched by 73 individuals), information technology services (watched by 91 individuals), transportation services (watched by 85 individuals), energy production (watched by 103 individuals), tea production and trading (watched by 48 individuals), export advice (watched by 21 individuals), and tax advice (watched by 5 individuals). The participants were free to choose which video to watch. The distribution was robust, which was essential to the analysis. Participants were in the following age ranges: under 18 years (31 participants), from 18-24 years (313 participants), from 25-34 years (51 participants), from 35-44 years (18 participants), from 45-55 years (11 participants), and over 56 years (2 participants). While 113 participants had already participated in some form of entrepreneurship education, 313 reported no prior participation in entrepreneurship education of any kind.

\subsection{Measurements}

In general, the success or failure of variables was measured using statements made by the entrepreneurs during their videos. To measure the stories' effectiveness, two categories of the statement were created, positive and negative, and statements from each video were 
categorised as one or the other. Participants were asked to classify the statements for true or wrong.

Success and failure stories. The entrepreneurs highlighted the successes and failures in their entrepreneurial lives with particular statements. If participants remembered the statements correctly after watching the story, the statement was assigned a value of 1 . Prior research was taken into account when applying this method of scoring narratives (e.g., Harmeling and Sarasvathy, 2013). Table 4 in the Appendix presents the statements and their associated scores, including the means and standard deviations (SD).

Role models. Participants were asked if they had an entrepreneurial role model and, if so, who it was. They were asked to evaluate their entrepreneurial role models, including four items entitled 'parents or siblings', 'friends', 'someone else who is important to me and/or someone I do not know personally', and 'the entrepreneur from the video' on a seven-point scale, with 1 meaning completely disapprove of and 7 meaning completely approve. The Cronbach's alpha for this measure was 0.74. Table 5 in the Appendix shows the mean, SD, item total correlation, and the Cronbach's alpha if the item was deleted.

Self-efficacy. Participants indicated their level of agreement (from 1 for strongly disagree to 7 for strongly agree) with 10 statements related to various tasks required to become an entrepreneur. For instance, based on items identified by Chen et al. (2001) and Kickul et al. (2009) regarding the search stage of entrepreneurship, a participant stated their agreement regarding Task 1 , which was to conceive a unique idea for a business. Other tasks measured the marshalling stage and the implementation stage. In principle, all the items reflected the entrepreneurial self-efficacy variable, which relates to "one's estimate of one's overall ability to perform successfully in a wide variety of achievement situations, or to how confident one is that she or he can perform effectively across different tasks and situations" (Chen et al., 2001, 63). The Cronbach's alpha for this measure was 0.938 . Table 6 in the Appendix lists the tasks, including the means, SD, item total correlation, and the Cronbach's alpha if the task was deleted.

Perceived behavioural control $(P B C)$. Based on items identified by Liñán and Chen (2009), participants indicated their level of agreement (with 1 indicating strong disagreement and 7 indicating strong agreement) with statements regarding their entrepreneurial capacity. The present study assessed PBC by the extent to which a person rated founding a business as feasible and the extent to which he or she felt well prepared. To this end, the study rated 6 items measuring PBC on a 7-point Likert scale. The Cronbach's alpha for this measure was 0.935 . Table 7 in the Appendix contains the items, including the means, SD, item total correlation, and the Cronbach's alpha if the item was deleted.

\subsection{Control variables}

Prior studies have found significant gender-related differences in perceived entrepreneurial self-efficacy and PBC (e.g., Martin et al., 2013; Shinnar et al., 2014) in the context of entrepreneurship education and other frameworks related to entrepreneurial orientation (e.g., Powell and Eddleston, 2013; Goktan and Gupta, 2013; Kelley et al., 2016; Fellnhofer et al., 2016). Thus, the present study controlled for gender. In addition, age has been found to be related to both PBC (e.g., Rauch and Hulsink, 2015) and 
entrepreneurial self-efficacy (e.g., Vázquez et al., 2011), which led to the decision to control for age, as it was expected that the course format used in the study did not suit all age groups equally well. Furthermore, entrepreneurial experience was controlled for and evaluated with yes or no questions based on those suggested by Peterman and Kennedy (2003), which asked whether the participant, parents, other family members, friends, or another person important to the participant had ever started a business and whether the participant had any work experience in a small or new business or in self-employment or as an entrepreneur. Finally, it has been controlled for nationality during the course of this research in the examination of 426 individuals from Austria, Finland and Greece to identify potential differences in different countries.

\subsection{Data validity and reliability}

Table 1 illustrates the results of a confirmatory factor analysis (CFA) summarising eight checks, labelled (a)-(h), for validity and reliability. As shown in (a), all standardised factor loadings (SFLs) were significant $(t>3.1 ; p<0.001)$. As shown in (b), based on Bagozzi and Baumgartner (1994), the indicator reliability (IR) of all items was $>0.4$. As shown in (c), according to Bagozzi and Yi (1988) and Raykov (1997), the composite reliability (CR) of the variables was $>0.6$. As shown in (d), all Cronbach's alphas were $>0.7$, as recommended by Nunnally (1978) and Hair et al. (1995). As shown in (e), according to Fornell and Larcker (1981), the average amount of variance (AVE) reflected was $>0.5$. As shown in (f), all Kaiser-Meyer-Olkin Measures of Sampling Adequacy $(\mathrm{KMO})$ were $>0.5$ (Kaiser, 1974). As shown in (g), all determinants of the constructs' correlation matrices were $>0.00001$. The variable self-efficacy is below but with respect to the robustness of all the other indicators, this value can be neglected. As shown in $(\mathrm{h})$, all significant values expressing the results of Bartlett's Test of Sphericity (BTS) showed suitable correlations in the dataset (Bartlett, 1937).

Table 1 Confirmatory factor analysis (CFA) results

\begin{tabular}{|c|c|c|c|c|c|c|c|c|c|}
\hline 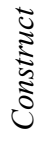 & Items & $\begin{array}{c}(a) \\
S F L\end{array}$ & $\begin{array}{c}(b) \\
I R \\
\geq 0.4\end{array}$ & $\begin{array}{c}(c) \\
C R \\
\geq 0.6\end{array}$ & $\begin{array}{c}(d) \\
\text { Cronbach's } \\
\alpha \geq 0.7\end{array}$ & $\begin{array}{c}(e) \\
A V E \geq \\
0.5\end{array}$ & $\begin{array}{c}(f) \\
K M O\end{array}$ & $\begin{array}{c}(g) \\
D \\
\geq 0.00001\end{array}$ & $\begin{array}{c}(h) \\
B T S\end{array}$ \\
\hline \multirow{4}{*}{ 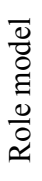 } & RM_1 & 0.664 & 0.441 & 0.755 & 0.74 & 0.652 & 0.684 & 0.365 & 426.056 \\
\hline & RM_2 & 0.886 & 0.785 & & & & & & \\
\hline & RM_3 & 0.548 & 0.3 & & & & & & \\
\hline & RM_4 & 0.511 & 0.261 & & & & & & \\
\hline \multirow{10}{*}{ 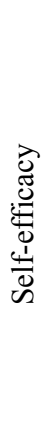 } & SE_S_1 & 0.724 & 0.524 & 0.938 & 0.938 & 0.777 & 0.91 & 0.000 & 3362.571 \\
\hline & SE_S_2 & 0.818 & 0.669 & & & & & & \\
\hline & SE_P_1 & 0.844 & 0.713 & & & & & & \\
\hline & SE_P_2 & 0.765 & 0.585 & & & & & & \\
\hline & SE_M_1 & 0.755 & 0.57 & & & & & & \\
\hline & SE_M_2 & 0.771 & 0.594 & & & & & & \\
\hline & SE_M_3 & 0.702 & 0.492 & & & & & & \\
\hline & SE_M_4 & 0.805 & 0.648 & & & & & & \\
\hline & SE_I_1 & 0.782 & 0.611 & & & & & & \\
\hline & SE_I_2 & 0.8 & 0.64 & & & & & & \\
\hline
\end{tabular}


Table 1 Confirmatory factor analysis (CFA) results (continued)

\begin{tabular}{|c|c|c|c|c|c|c|c|c|c|}
\hline 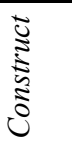 & Items & $\begin{array}{c}\text { (a) } \\
\text { SFL }\end{array}$ & $\begin{array}{c}(b) \\
I R \\
\geq 0.4\end{array}$ & $\begin{array}{c}(c) \\
C R \\
\geq 0.6\end{array}$ & $\begin{array}{c}(d) \\
\text { Cronbach's } \\
\alpha \geq 0.7\end{array}$ & $\begin{array}{c}(e) \\
A V E \geq \\
0.5\end{array}$ & $\begin{array}{c}(f) \\
K M O\end{array}$ & $\begin{aligned} &(g) \\
& D \\
& \geq 0.00001\end{aligned}$ & $\begin{array}{c}(h) \\
B T S\end{array}$ \\
\hline \multirow{6}{*}{ 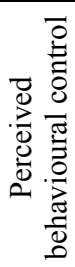 } & $\mathrm{BC} \_1_{-}$ & 0.815 & 0.664 & 0.932 & 0.935 & 0.833 & 0.895 & 0.006 & 2129.336 \\
\hline & BC_2 & 0.861 & 0.741 & & & & & & \\
\hline & BC_3 & 0.892 & 0.796 & & & & & & \\
\hline & BC_4 & 0.807 & 0.651 & & & & & & \\
\hline & BC_5 & 0.826 & 0.682 & & & & & & \\
\hline & BC_6 6 & 0.797 & 0.636 & & & & & & \\
\hline
\end{tabular}

\section{Results}

Table 2 shows the construct means, SD, and correlations of all study variables and shows that the means were equal for stories of success and failure. In accordance with the recommendations of Tabachnick and Fidell (1996), the bivariate correlation between the independent variables did not exceed 0.70 . Thus, multicollinearity does not appear to have been a critical issue in this research. In addition, the variance inflation factor (VIF) was below the acceptable level of 2.5 (Baguley, 2012).

Table 2 Construct means, SD, and correlations of study variables

\begin{tabular}{llccccccr}
\hline & Mean & $S D$ & 1 & 2 & 3 & 4 & 5 \\
\hline 1 & Role model & 4.00 & 1.31 & 1 & & & & \\
2 & Self-efficacy & 4.43 & 1.17 & $0.295^{* *}$ & 1 & & & \\
3 & Success stories & 0.08 & 0.06 & -0.014 & 0.086 & 1 & & \\
4 & Failure stories & 0.08 & 0.06 & 0.049 & $0.102^{*}$ & $0.603 * *$ & 1 & \\
5 & Perceived behaviour control & 3.67 & 1.38 & $0.252^{* *}$ & $0.656^{* *}$ & 0.041 & 0.044 & 1 \\
\hline
\end{tabular}

$n=426$; Pearson correlation (bivariate); standard deviation (SD).

*Correlation is significant at the 0.05 level (2-tailed). $* *$ Correlation is significant at the 0.01 level (2-tailed).

In addition, the data $(n=426)$ were analysed using linear regression examinations for the model. Table 3 shows the results. First, Hypothesis 1 (H1) proposed that observing either entrepreneurial success stories (H1a) or entrepreneurial failure stories (H1b) in the course of a web-based entrepreneurship training program would influence perceptions of role models. The results indicated that neither stories of success $(B=-0.886$, n.s. $)$ nor stories of failure $(B=0.573$, n.s.) significantly influenced the participants' perceptions of roles models. Therefore, H1 was not supported. In addition, it did not matter whether role models shared negative or positive experiences with nascent entrepreneurs. However, the results did support hypothesis 2 (H2), demonstrating that role models do have a significant positive influence on entrepreneurial self-efficacy $\left(B=0.230^{* * *}, p<0.01\right)$. Hypothesis 3, which proposed that exposure to entrepreneurial self-efficacy would increase entrepreneurial $\mathrm{PBC}$, was also supported because a significant positive effect 
was found $(B=0.702 * * *, p<0.01)$. While nationality appears to have no significant influence of the variables under investigation, entrepreneurial experience and gender appear to play a significant role. The higher the experience, the higher is the impact of role models, entrepreneurial self-efficacy and PBC. Furthermore, males tend to perceive entrepreneurial self-efficacy and PBC higher than females after observing entrepreneurial stories.

Table 3 The model's linear regression results $(n=426)$

\begin{tabular}{|c|c|c|c|c|c|c|c|c|}
\hline & \multicolumn{4}{|c|}{$H 1$} & \multicolumn{2}{|c|}{$H 2$} & \multicolumn{2}{|c|}{$H 3$} \\
\hline & \multicolumn{4}{|c|}{ Role model } & \multicolumn{2}{|c|}{$\begin{array}{l}\text { Entrepreneurial } \\
\text { self-efficacy }\end{array}$} & \multicolumn{2}{|c|}{$\begin{array}{c}\text { Perceived } \\
\text { behaviour control }\end{array}$} \\
\hline & $B$ & $S E$ & $B$ & $S E$ & $B$ & $S E$ & $B$ & $S E$ \\
\hline \multicolumn{9}{|c|}{ Independent variables } \\
\hline (constant) & $3.707 * * *$ & 0.334 & $3.637 * * *$ & 0.336 & $2.734 * * *$ & 0.318 & $-0.879 * * *$ & 0.298 \\
\hline Success stories & -0.886 & 1.069 & & & & & & \\
\hline Failure stories & & & 0.573 & 1.042 & & & & \\
\hline Role model & & & & & $.230 * * *$ & 0.041 & & \\
\hline \multirow{2}{*}{$\begin{array}{l}\text { Entrepreneurial } \\
\text { self-efficacy }\end{array}$} & & & & & & & $0.702 * * *$ & 0.043 \\
\hline & \multicolumn{4}{|c|}{ Control variables } & & & & \\
\hline $\begin{array}{l}\text { Entrepreneurial } \\
\text { experience }\end{array}$ & $1.095 * * *$ & 0.260 & $1.058 * * *$ & 0.260 & $1.054 * * *$ & 0.223 & $0.807 * * *$ & 0.207 \\
\hline Age & $-0.157 *$ & 0.082 & $-0.155^{*}$ & 0.082 & -0.021 & 0.070 & $0.222 * * *$ & 0.063 \\
\hline Gender & -0.011 & 0.131 & -0.023 & 0.131 & $.317 * * *$ & 0.111 & $0.367 * * *$ & 0.102 \\
\hline Nationality & 0.027 & 0.021 & 0.027 & 0.021 & 0.010 & 0.018 & -0.014 & 0.016 \\
\hline Field of study & 0.016 & 0.027 & 0.012 & 0.027 & -0.027 & 0.023 & -0.013 & 0.021 \\
\hline $\begin{array}{l}\text { Entrepreneur } \\
\text { watched }\end{array}$ & 0.024 & 0.047 & 0.025 & 0.047 & -0.032 & 0.039 & 0.023 & 0.036 \\
\hline$R$-Square & \multicolumn{2}{|c|}{0.053} & \multicolumn{2}{|c|}{0.052} & \multicolumn{2}{|c|}{0.158} & \multicolumn{2}{|c|}{0.494} \\
\hline Adjusted R-Square & \multicolumn{2}{|c|}{0.037} & \multicolumn{2}{|c|}{0.036} & \multicolumn{2}{|c|}{0.144} & \multicolumn{2}{|c|}{0.486} \\
\hline$F$ & \multicolumn{2}{|c|}{$3.330 * *$} & \multicolumn{2}{|c|}{$3.272 * * *$} & \multicolumn{2}{|c|}{$11.217 * * *$} & \multicolumn{2}{|c|}{$58.311 * * *$} \\
\hline
\end{tabular}

Standard error (SE), unstandardised coefficients B (B), Significance codes: ${ }^{*} p<0.1$, $* * p<0.05, * * * p<0.01$.

Finally, as the results of the linear regression analysis indicated, the research model, which assumed a causal chain from role models' entrepreneurial stories to the intervening concepts, including self-efficacy, had a significant positive effect on the results of entrepreneurship education about entrepreneurial PBC (Figure 2). Overall, there is no significant effect on the perception of role models when potential entrepreneurs listen to success $(B=-0.886$, n.s.) or failure stories $(B=0.573$, n.s.) of entrepreneurs. In other words, it does not matter whether the role models observed focus on the positive or negative aspects of their entrepreneurial experiences. However, overall participants' perceptions of entrepreneurial self-efficacy were significantly positively affected by observing role models $\left(B=-0.230^{* * *}\right)$ in the context of multimedia entrepreneurship 
education, and this effect on perception significantly increased entrepreneurial $\mathrm{PBC}$ $\left(B=0.702^{* * *}\right)$.

Baron and Kenny (1986) proposed a four step approach in which several regression analyses are conducted for testing mediation with regression analysis. Because there are significant relationships from entrepreneurial role models through perceived behaviour control, it has been proceeded to test mediation with regression analysis. This holds true in this model. In the fourth step, mediation is supported if the effect of entrepreneurial self-efficacy remains significant after controlling for entrepreneurial role models. Because entrepreneurial role model is still significant $\left(B=0.187^{* * *}\right)$ when entrepreneurial self-efficacy is controlled $\left(B=0.632^{* * *}\right)$, the finding supports partial mediation (adjusted $R$ Square $=0.510 ; F=50.193^{* * *}$ ).

Figure 2 Research model results with unstandardised coefficients $B$

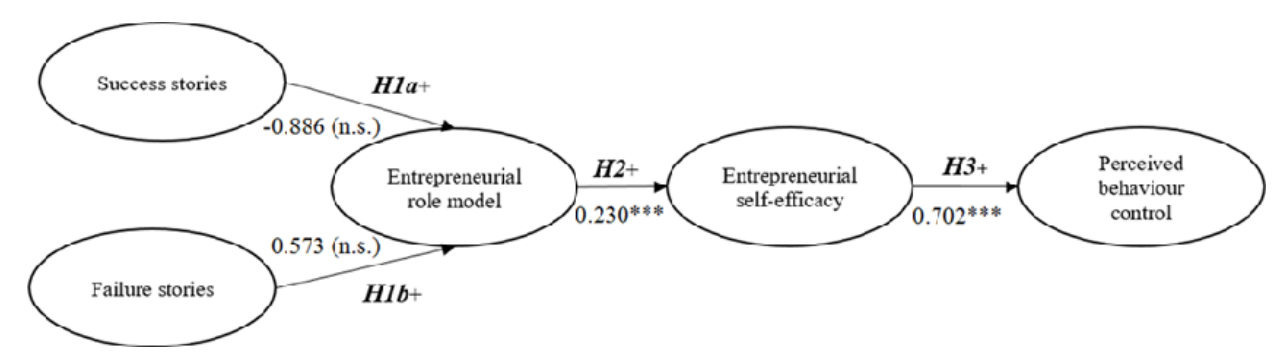

Significance code: $* * * p<0.01$.

\section{Discussion and conclusions}

The central purpose of this study was to investigate the effects of entrepreneurial role models on entrepreneurship education using the TPB (Ajzen, 1988), social learning theory (Bandura, 1986) and Dyer's (1994) model of entrepreneurial careers. The study aimed to fill a gap in research on the effects of roles models on entrepreneurial PBC. Results showed that role models in entrepreneurship education had a significant positive effect on participants' self-efficacy and PBC to become an entrepreneur.

Results of the present study will contribute threefold to the ongoing debate in the entrepreneurship-education literature. First, the findings emphasised that Ajzen's fundamental theory (1988) offers a valuable framework for understanding the effects of role models in entrepreneurship education about entrepreneurial PBC. The present study enhanced the existing academic discussion by showing that observing role models affect perceptions. Within this framework, this study highlighted the content in multimedia storytelling and its effects in the course of entrepreneurship education. It made no difference whether entrepreneurs stressed the negative or positive aspects of the entrepreneurial life or both. This understanding will aid the design of effective, practical entrepreneurship courses (Edelman et al., 2008).

Second, the present study demonstrated that role models in entrepreneurship education affected entrepreneurial PBC via self-efficacy, the effect of which was significantly positive. Therefore, entrepreneurial role models deserve more of a role in entrepreneurship education designed to give students a realistic picture of being an entrepreneur. This engagement need not necessarily focus on entrepreneurship's positive 
or negative aspects, but it should motivate and inspire participants. For instance, several researchers have noted that emotions and passion strongly enhanced entrepreneurship education (e.g., Souitaris et al., 2007; Bhoyar and Nagendra, 2014; Lyons et al., 2015), as they are essential to the entrepreneurial temperament (Cardon et al., 2013).

Finally, while the present study provided no recommendations regarding the most suitable course design to ensure entrepreneurship education that stimulates entrepreneurial $\mathrm{PBC}$, it provided evidence that entrepreneurial role models increased entrepreneurial $\mathrm{PBC}$ via self-efficiency. Furthermore, integrating role models in the curriculum or merge them with other entrepreneurship-education curriculum design, for instance, with game-based learning (e.g., Xinaris et al., 2011; Fellnhofer, 2015), opportunity identification (DeTienne and Chandler, 2004), entrepreneurial action (Neck and Greene, 2011), or out of a diverse teaching pool (Lorz et al., 2013; Gedeon, 2014) shows great potential.

\subsection{Limitations}

The results of the present study must be interpreted with caution. First, the study used only the results of a post-assessment questionnaire on a web-based entrepreneurial program. In addition, the generalisability of its findings may be limited by regional and national differences in PBC, as highlighted by prior studies (e.g., Bernhofer and Han, 2014). In addition, this study illuminates light on the influence of different role models outside the classroom. Thus, to which extent these effects could be integrated into the curriculum requires further research effort. Furthermore, its results regarding the type of web-based entrepreneurship education used must be compared to the results of other research designs. Furthermore, when explaining and demonstrating the mediating role of entrepreneurial self-efficacy in the effect of entrepreneurial role model on perceived behavioural control, bootstrapping mediation analysis could be also used. A bootstrapping approach to mediation analyses would allow further findings when testing the significance of the indirect effects (Hayes, 2009; Shrout and Bolger, 2002). Finally, the study did not include all elements of the TPB, which leaves room for further research, as do the complexities of entrepreneurship education in general.

\subsection{Future research}

Various future research avenues present themselves. Although the present study confirmed that role models in the context of entrepreneurship education increased entrepreneurial $\mathrm{PBC}$, future research is required to inspect the contextual issues in more detail than the present framework allowed. For instance, analysing the mediating and moderating effects using structural equation models would provide further interesting insights into how entrepreneurial PBC is affected at various levels.

\subsection{Practical implications}

From a practical viewpoint, entrepreneurship education aims to have a positive effect on potential entrepreneurs, increasing their motivation to choose such a non-traditional career path regardless of age, gender, education, and social or cultural background. Entrepreneurship education is as complex and multifaceted as entrepreneurship itself. At its heart, entrepreneurship education should illuminate a promising, valuable path for 
potential entrepreneurs. Consequently, entrepreneurship education must go beyond the transfer of knowledge and understanding of theoretical constructs to shape future reality in practice (Neck and Greene, 2011). This study proposed one element for entrepreneurship education and raised valuable issues that must be considered in future research. Meanwhile, both educational and social institutions must identify ways to become more supportive of entrepreneurial creativity, inspiration, and innovation (Walter and Block, 2016).

\section{Acknowledgements}

The author would like to thank the Austrian Science Fund FWF [J3740] for supporting this research project.

\section{References}

Ajzen, I. (1988) Attitudes, Personality and Behavior, Dorsey Press, Chicago, IL.

Ajzen, I. (1991) 'The theory of planned behavior', Organizational Behavior and Human Decision Processes, Vol. 50, No. 2, pp.179-211.

Ajzen, I. and Fishbein, M. (1977) 'Attitude-behavior relations: a theoretical analysis and review of empirical research', Psychological Bulletin, Vol. 84, No. 5, pp.888-918.

Albert, P., Fournier, R. and Marion, S. (1991) 'Developing entrepreneurial attitudes and management competence among scientists: the Groupe ESC Lyon's experience', Entrepreneurship and Regional Development, Vol. 3, No. 4, pp.349-362.

Aldrich, H., Renzulli, L.A. and Langton, N. (1998) 'Passing on privilege: resources provided by self-employed parents to their self-employed children', Research in Social Stratification and Mobility, Vol. 16, pp.291-318.

Anna, A.L., Chandler, G.N., Jansen, E. and Mero, N.P. (2000) 'Women business owners in traditional and non-traditional industries', Journal of Business Venturing, Vol. 15, No. 3, pp.279-303.

Arenius, P. and Minniti, M. (2005) 'Perceptual variables and nascent entrepreneurship', Small Business Economics, Vol. 24, No. 3, pp.233-247.

Aronson, J. (2004) 'The threat of stereotype', Educational Leadership, Vol. 62, No. 3, pp.14-20.

Athayde, R. (2009) 'Measuring enterprise potential in young people', Entrepreneurship Theory and Practice, Vol. 33, No. 2, pp.481-500.

Bagozzi, R.P. and Baumgartner, H. (1994) 'The evaluation of structural equation models and hypotheses testing', in Bagozzi, R.P. (Ed.): Principles of Marketing Research, Blackwell, Cambridge, pp.386-422.

Bagozzi, R.P. and Yi, Y. (1988) 'On the evaluation of structural equation models', Journal of the Academy of Marketing Science, Vol. 16, No. 1, pp.74-94.

Baguley, T. (2012) Serious Stats: A Guide to Advanced Statistics for the Behavioral Sciences, Palgrave Macmillan, Basingstoke.

Bandura, A. (1977) Social Learning Theory Englewood Cliffs, Prentice-Hall, NJ.

Bandura, A. (1986) Social Foundations of Thought and Action: A Social Cognitive Theory, Englewood Cliffs, Prentice-Hall, NJ.

Barbosa, S., Dubard, G., Megan, W. and Kickul, J.R. (2007) 'The role of cognitive style and risk preference on entrepreneurial self-Efficacy and entrepreneurial intentions', Journal of Leadership and Organizational Studies, Vol. 13, No. 4, pp.86-104. 
Baron, R.M. and Kenny, D.A. (1986) 'The moderator-Mediator variable distinction in social psychological research: conceptual, strategic and statistical considerations', Journal of Personality and Social Psychology, Vol. 51, No. 6, pp.1173.

Bartlett, M. (1937) 'Properties of sufficiency and statistical tests', Proceedings of the Royal Statistical Society Series A., Vol. 160, No. 901, 18 May, 1937, pp.268-282.

Bernhofer, L. and Han, Z. (2014) 'Contextual factors and their effects on future entrepreneurs in China: a comparative study of entrepreneurial intentions', International Journal of Technology Management, Vol. 65, Nos. 1-4, pp.125-150.

Bessant, J. and Rush, H. (1995) 'Building bridges for innovation: the role of consultants in technology transfer', Research Policy, Vol. 24, No. 1, pp.97-114.

Bhoyar, P.K. and Nagendra, A. (2014) 'Due diligence to assess and validate the students entrepreneurs and their business plans - an investors' contemporary approach', in Londhe, B.R., Divekar, R. and Chandani, A. (Eds.): Shaping the Future of Business and Society - Symbiosis Institute of Management Studies, Elsevier Science Bv, Amsterdam, pp.737-744.

Bird, B., Schjoedt, L. and Baum, J.R. (2012) 'Editor's introduction. entrepreneurs' behavior: elucidation and measurement', Entrepreneurship Theory and Practice, Vol. 36, No. 5, pp.889-913.

Bosma, N., Hessels, J., Schutjens, V., Van Praag, M. and Verheul, I. (2012) 'Entrepreneurship and role models', Journal of Economic Psychology, Vol. 33, No. 2, pp.410-424.

Boyles, T. (2012) '21st century knowledge, skills and abilities and entrepreneurial competencies: a model for undergraduate entrepreneurship education', Journal of Entrepreneurship Education, Vol. 15, No. n/a, pp.41-55.

Bridge, S., O’Neill, K. and Cromie, S. (1998) Understanding Enterprise, Entrepreneurship and Small Firms, Macmillan, London.

Callagher, L., Horst, M. and Husted, K. (2015) 'Exploring societal responses towards managerial prerogative in entrepreneurial universities', International Journal of Learning and Change, Vol. 8, No. 1, pp.64-82.

Cardon, M.S., Gregoire, D.A., Stevens, C.E. and Patel, P.C. (2013) 'Measuring entrepreneurial passion: conceptual foundations and scale validation', Journal of Business Venturing, Vol. 28, No. 3, pp.373-396.

Carter, N.M., Gartner, W.B., Shaver, K.G. and Gatewood, E.J. (2003) 'The career reasons of nascent entrepreneurs', Journal of Business Venturing, Vol. 18, No. 1, pp.13-39.

Carver, C.S., Scheier, M.F. and Segerstrom, S.C. (2010) 'Optimism', Clinical Psychology Review, Vol. 30, No. 7, pp.879-889.

Chen, C.C., Greene, P.G. and Crick, A. (1998) 'Does entrepreneurial self-efficacy distinguish entrepreneurs from managers?', Journal of Business Venturing, Vol. 13, No. 4, pp.295-316.

Chen, G., Gully, S.M. and Eden, D. (2001) 'Validation of a new general self-efficacy scale', Organizational Research Methods, Vol. 4, No. 1, pp.62-83.

Chen, G., Gully, S.M. and Eden, D. (2004) 'General self-efficacy and self-esteem: toward theoretical and empirical distinction between correlated self-Evaluations', Journal of Organizational Behavior, Vol. 25, No. 3, pp.375-395.

Chen, L. (2014) 'Understanding it entrepreneurial intention: an information systems view', The Journal of Computer Information Systems, Vol. 55, No. 1, pp.2-12.

Chlosta, S., Patzelt, H., Klein, S.B. and Dormann, C. (2012) 'Parental role models and the decision to become self-employed: the moderating effect of personality', Small Business Economics, Vol. 38, No. 1, pp.121-138.

Davidsson, P. and Honig, B. (2003) 'The role of social and human capital among nascent entrepreneurs', Journal of Business Venturing, Vol. 18, No. 1, pp.301-331. 
DeTienne, D.R. and Chandler, G.N. (2004) 'Opportunity identification and its role in the entrepreneurial classroom: a pedagogical approach and empirical test', Academy of Management Learning and Education, Vol. 3, No. 3, pp.242-257.

Dewhurst, D. and Lamb, S. (2005) 'Educational stories: engaging teachers in educational theory', Educational Philosophy and Theory, Vol. 37, No. 6, pp.907-917.

Dickson, P.H., Solomon, G.T. and Weaver, K.M. (2008) 'Entrepreneurial selection and success: does education matter?', Journal of Small Business and Enterprise Development, Vol. 15, No. 2, pp.239-258.

Drucker, P.F. (2011) The Age of Discontinuity: Guidelines to Our Changing Society, Transaction Publishers, New Brunswick (USA) and London (UK).

Dyer Jr., W. G. (1994) 'Toward a theory of entrepreneurial careers', Entrepreneurship: Theory and Practice, Vol. 19, No. 2, pp.7-22.

EC (2013) Entrepreneurship.2020 Action Plan. Communication from the Commission to the European Parliament, the Council, the European Economic and Social Committee and the Committee of the Regions, Reigniting the Entrepreneurial Spirit in Europe, EC, Brussels.

Edelman, L.F., Manolova, T.S. and Brush, C.G. (2008) 'Entrepreneurship education: correspondence between practices of nascent entrepreneurs and textbook prescriptions for success', Academy of Management Learning and Education, Vol. 7, No. 1, pp.56-70.

Fayolle, A., Gailly, B. and Lassas-Clerc, N. (2006) 'Assessing the impact of entrepreneurship education programmes: a new methodology', Journal of European Industrial Training, Vol. 30, Nos. 8-9, pp.701-720.

Fellnhofer, K. (2015) 'Unternehmerische bewusstseinsbildung und -Förderung durch game-Based learning als instrument der entrepreneurship education: eine fallstudie', Zeitschrift Für Kmи Und Entrepreneurship, Duncker and Humblot, Berlin, Vol. 63, No. 1, pp.25-46.

Fellnhofer, K., Puumalainen, K. and Sjögrén, H. (2016) 'Entrepreneurial orientation and performance - are sexes equal?', International Journal of Entrepreneurial Behavior and Research, Vol. 22, No. 3, pp.346-374.

Ferreira, J.J. and Fernandes, C. (2012) 'Cooperation between KIBS and universities: an empirical study', IFKAD - KCWS 2012:7th International Forum on Knowledge Asset Dynamics, 5th Knowledge Cities World Summit: Knowledge, Innovation and Sustainability: Integrating Micro and Macro Perspectives, pp.1377-1393.

Fornell, C. and Larcker, D.F. (1981) 'Structural equation models with unobservable variables and measurement error: algebra and statistics', Journal of Marketing Research, Vol. 18, No. 3, pp.382-388.

Gartner, W.B. and Vesper, K.H. (1994) 'Experiments in entrepreneurship education - successes and failures', Journal of Business Venturing, Vol. 9, No. 3, pp.179-187.

Gedeon, S.A. (2014) 'Application of best practices in university entrepreneurship education', European Journal of Training and Development, Vol. 38, No. 3, pp.231-253.

Gibb, D.W. (1994) 'Toward a theory of entrepreneurial careers', Entrepreneurship: Theory and Practice, Vol. 19, No. 2, pp.7-22.

Gibson, D.E. (2004) 'Role models in career development: new directions for theory and research', Journal of Vocational Behavior, Vol. 65, No. 1, pp.134-156.

Glaub, M.E., Frese, M., Fischer, S. and Hoppe, M. (2014) 'Increasing personal initiative in small business managers or owners leads to entrepreneurial success: a theory-based controlled randomized field intervention for evidence-based management', Academy of Management Learning and Education, Vol. 13, No. 3, pp.354-379.

Goktan, A.B. and Gupta, V.K. (2013) 'Sex, gender and individual entrepreneurial orientation: evidence from four countries', International Entrepreneurship and Management Journal, Vol. 11, No. 1, pp.95-112.

Gorman, G. and Hanlon, D. (1997) 'Some research perspectives on entrepreneurship education, enterprise education and education for small business management: a ten-year literature review', International Small Business Journal, Vol. 15, No. 3, pp.56-78. 
Hair, J.F., Anderson, R.E., Tatham, R.L. and Black, W.C. (1995) Multivariate Data Analyses with Readings, Prentice-Hall College Div, NJ.

Hansson, H., Ferguson, R. and Olofsson, C. (2012) 'Psychological constructs underlying farmers' decisions to diversify or specialise their businesses - an application of theory of planned behaviour', Journal of Agricultural Economics, Vol. 63, No. 2, pp.465-482.

Harmeling, S.S. and Sarasvathy, S.D. (2013) 'When contingency is a resource: educating entrepreneurs in the Balkans, the Bronx and beyond', Entrepreneurship: Theory and Practice, Vol. 37, No. 4, pp.713-744.

Hayes, A.F. (2009) 'Beyond Baron and Kenny: statistical mediation analysis in the new millennium', Communication Monographs, Vol. 76, No. 4, pp.408-420.

Henry, C., Hill, F. and Leitch, C. (2005) 'Entrepreneurship education and training: can entrepreneurship be taught? Part I', Education + Training, Vol. 47, No. 2, pp.98-111.

Hout, M. and Rosen, H.S. (1999) Self-Employment, Family Background and Race, National Bureau of Economic Research, Cambridge.

Ianioglo, A. and Polajeva, T. (2017) 'The essence and phases of the comprehensive system of ensuring the economic security of enterprise', International Journal of Learning and Change, Vol. 9, No. 1, pp.59-74.

Kaiser, H.F. (1974) 'An index of factorial simplicity', Psychometrika, Vol. 39, No. 1, pp.31-36.

Kautonen, T., Gelderen, M. and Fink, M. (2013) 'Robustness of the theory of planned behavior in predicting entrepreneurial intentions and actions', Entrepreneurship: Theory and Practice, Vol. 39, No. 3, pp.655-674.

Kelley, D., Singer, S. and Herrington, M. (2016) 2015/16 Global Report - GEM Global Entrepreneurship Monitor, in (GERA), G.E.R.A. (editor. Babson Park, MA, USA; Santiago, Chile; Malaysia; Mexiko; London, UK: Babson College, Universidad del Desarrollo, Universiti Tun Abdul Razak, Tecnológico de Monterrey, London Business School).

Kickul, J., Gundry, L.K., Barbosa, S.D. and Whitcanack, L. (2009) 'Intuition versus analysis? testing differential models of cognitive style on entrepreneurial self-efficacy and the new venture creation process', Entrepreneurship Theory and Practice, Vol. 33, No. 2, pp.439-453.

Klapper, R.G. (2014) 'A role for George Kelly's repertory grids in entrepreneurship education? evidence from the French and polish context', The International Journal of Management Education, Vol. 12, No. 3, pp.407-421.

Kolvereid, L. (1996) Prediction of Employment Status Choice Intentions, Working Paper Series. Henley: Henley Management College HWP.

Kolvereid, L. and Moen, Ø. (1997) 'Entrepreneurship among business graduates: does a major in entrepreneurship make a difference?', Journal of European Industrial Training, Vol. 21, No. 4, pp.154-160.

Krueger, N.F. (2009) 'The microfoundations of entrepreneurial learning and... education: the experiential essence of entrepreneurial cognition', in West III, G.P., Gatewood, E.J. and Shaver, K.G. (Ed.): Handbook of University-Wide Entrepreneurship Education, Edward Elgar, NJ, pp.35-59.

Krueger, N.F., Reilly, M.D. and Carsrud, A.L. (2000) 'Competing models of entrepreneurial intentions', Journal of Business Venturing, Vol. 15, No. 5, pp.411-432.

Kuckertz, A. (2013) 'Entrepreneurship education: status quo and prospective developments', Journal of Entrepreneurship Education, Vol. 16, pp.59-71.

Kuratko, D.F. (2005) 'The emergence of entrepreneurship education: development, trends and challenges', Entrepreneurship: Theory and Practice, Vol. 29, No. 5, pp.577-597.

Lerner, M., Brush, C. and Hisrich, R. (1997) 'Israeli women entrepreneurs: an examination of factors affecting performance', Journal of Business Venturing, Vol. 12, No. 4, pp.315-339.

Li, Y., Wang, P. and Liang, Y-J. (2015) 'Influence of entrepreneurial experience, alertness and prior knowledge on opportunity recognition', Social Behavior and Personality: An International Journal, Vol. 43, No. 9, pp.1575-1583. 
Lin, S. and Si, S. (2014) 'Factors affecting peasant entrepreneurs' intention in the Chinese context', International Entrepreneurship and Management Journal, Vol. 10, No. 4, pp.803-825.

Liñán, F. (2004) 'Intention-Based models of entrepreneurship education', Piccola Impresa/Small Business, Vol. 3, No. 1, pp.11-35.

Liñán, F. and Chen, Y-W. (2009) 'Development and cross-cultural application of a specific instrument to measure entrepreneurial intentions', Entrepreneurship: Theory and Practice, Vol. 33, No. 3, pp.593-617.

Liñán, F., Rodríguez-Cohard, J.C. and Rueda-Cantuche, J.M. (2011) 'Factors affecting entrepreneurial intention levels: a role for education', International Entrepreneurship and Management Journal, Vol. 7, No. 2, pp.195-218.

Lockwood, P. (2006) 'Someone like me can be successful': do college students need same-gender role models?', Psychology of Women Quarterly, Vol. 30, No. 1, pp.36-46.

Lois, D., Moriano, J.A. and Rondinella, G. (2015) 'Cycle commuting intention: a model based on theory of planned behaviour and social identity', Transportation Research: Part F, Vol. 32, July, pp.101-113.

Lorz, M., Mueller, S. and Volery, T. (2013) 'Entrepreneurship education: a systematic review of the methods in impact studies', Journal of Enterprising Culture, Vol. 21, No. 2, pp.123-151.

Lyons, R., Lynn, T. and Bhaird, C.M.A. (2015) 'Individual level assessment in entrepreneurship education: an investigation of theories and techniques', Journal of Entrepreneurship Education, Vol. 18, No. 1, pp.136-156.

Malebana, M.J. (2017) 'Knowledge of entrepreneurial support and entrepreneurial intention in the rural provinces of South Africa', Development Southern Africa, Vol. 34, No. 1, pp.74-89.

Marques, C.S., Gomes, D., Ferreira, J. and Rodrigues, R. (2012) 'Factors preceding the formation of entrepreneurial intention: an applied study of secondary school students', Proceedings of the 7th European Conference on Innovation and Entrepreneurship, Vols. 1 and 2, pp.456-465.

Martin, B.C., McNally, J.J. and Kay, M.J. (2013) 'Examining the formation of human capital in entrepreneurship: a meta-Analysis of entrepreneurship education outcomes', Journal of Business Venturing, Vol. 28, No. 2, pp.211-224.

Matlay, H. and Harmeling, S.S. (2011) 'Re-Storying an entrepreneurial identity: education, experience and self-narrative', Education+ Training, Vol. 53, Nos. 8-9, pp.741-749.

Matlay, H. and Matlay, H. (2006) 'Researching entrepreneurship and education: part 2: what is entrepreneurship education and does it matter?', Education+ Training, Vol. 48, Nos. 8-9, pp.704-718.

McGee, J.E., Peterson, M., Mueller, S.L. and Sequeira, J.M. (2009) 'Entrepreneurial self-efficacy: refining the measure', Entrepreneurship: Theory and Practice, Vol. 33, No. 4, pp.965-988.

McKeon, H., Johnston, K. and Henry, C. (2004) 'Multinational companies as a source of entrepreneurial learning: examples from the IT sector in IRELAND', Education+ Training, Vol. 46, Nos. 8-9, pp.433-443.

McMillan, B., Conner, M., Woolridge, M., Dyson, L., Green, J., Renfrew, M., Bharj, K. and Clarke, G. (2008) 'Predicting breastfeeding in women living in areas of economic hardship: explanatory role of the theory of planned behaviour', Psychology and Health, Vol. 23, No. 7, pp.767-788.

McMullan, W.E. and Long, W.A. (1987) 'Entrepreneurship education in the nineties', Journal of Business Venturing, Vol. 2, No. 3, pp.261-275.

Muofhe, N.J. and du Toit, W.F. (2011) 'Entrepreneurial education's and entrepreneurial role models' influence on career choice', South African Journal of Human Resource Management, Vol. 9, No. 1, pp.243-257.

Mustar, P. (2009) 'Technology management education: innovation and entrepreneurship at mines ParisTech, a leading French engineering school', Academy of Management Learning and Education, Vol. 8, No. 3, pp.418-425. 
Mwasalwiba, E.S. (2010) 'Entrepreneurship education: a review of its objectives, teaching methods and impact indicators', Education+ Training, Vol. 52, No. 1, pp.20-47.

Neck, H.M. and Greene, P.G. (2011) 'Entrepreneurship education: known worlds and new frontiers', Journal of Small Business Management, Vol. 49, No. 1, pp.55-70.

Nunnally, J. (1978) Psychometric Theory, McGraw-Hill, New York.

Oosterbeek, H., van Praag, M. and Ijsselstein, A. (2010) 'The impact of entrepreneurship education on entrepreneurship skills and motivation', European Economic Review, Vol. 54, No. 3, pp.442-454.

Peterman, N.E. and Kennedy, J. (2003) 'Enterprise education: influencing students' perceptions of entrepreneurship', Entrepreneurship: Theory and Practice, Vol. 28, No. 2, pp.129-144.

Pihie, Z.A.L. and Bagheri, A. (2013) 'Self-Efficacy and entrepreneurial intention: the mediation effect of self-regulation', Vocations and Learning, Vol. 6, No. 3, pp.385-401.

Pittaway, L. and Cope, J. (2007) 'Entrepreneurship education: a systematic review of the evidence', International Small Business Journal, Vol. 25, No. 5, pp.479-510.

Powell, G.N. and Eddleston, K.A. (2013) 'Linking family-to-business enrichment and support to entrepreneurial success: do female and male entrepreneurs experience different outcomes?', Journal of Business Venturing, Vol. 28, No. 2, pp.261-280.

Quimby, J.L. and Santis, A.M. (2006) 'The influence of role models on women's career choices', The Career Development Quarterly, Vol. 54, No. 4, pp.297-306.

Rahman, H. and Day, J. (2014) 'Involving the entrepreneurial role model: a possible development for entrepreneurship education', Journal of Entrepreneurship Education, Vol. 17, No. 2, pp.163-171.

Rasmussen, E.A. and Sorheim, R. (2006) 'Action-based entrepreneurship education', Technovation, Vol. 26, No. 2, pp.185-194.

Rauch, A. and Frese, M. (2007) 'Let's put the person back into entrepreneurship research: a meta-analysis on the relationship between business owners personality traits, business creation and success', European Journal of Work and Organizational Psychology, Vol. 16, No. 4, pp.353-385.

Rauch, A. and Hulsink, W. (2015) 'Putting entrepreneurship education where the intention to act lies: an investigation into the impact of entrepreneurship education on entrepreneurial behavior', Academy of Management Learning and Education, Vol. 14, No. 2, pp.187-204.

Raykov, T. (1997) 'Estimation of composite reliability for congeneric measures', Applied Psychological Measurement, Vol. 21, No. 2, pp.173-184.

Ritchie, J.S. and Wilson, D.E. (2000) Teacher Narrative as Critical Inquiry: Rewriting the Script, Teachers College Press, Amsterdam.

Robinson, P.B. and Sexton, E.A. (1994) 'The effect of education and experience on selfemployment success', Journal of Business Venturing, Vol. 9, No. 2, pp.141-156.

Roxas, B. (2014) 'Effects of entrepreneurial knowledge on entrepreneurial intentions: a longitudinal study of selected south-East Asian business students', Journal of Education and Work, Vol. 27, No. 4, pp.432-453.

Saeed, S., Yousafzai, S.Y., Yani-De-Soriano, M. and Muffatto, M. (2015) 'The role of perceived university support in the formation of students' entrepreneurial intention', Journal of Small Business Management, Vol. 53, No. 4, pp.1127-1145.

Schatz-Oppenheimer, O. and Dvir, N. (2014) 'From ugly duckling to swan: stories of novice teachers', Teaching and Teacher Education, Vol. 37, January, pp.140-149.

Schlaegel, C. and Koenig, M. (2014) 'Determinants of entrepreneurial intent: a meta-analytic test and integration of competing models', Entrepreneurship: Theory and Practice, Vol. 38, No. 2, pp.291-332.

Shahrabadi, R., Karimi-Shahanjarini, A., Dashti, S., Soltanian, A. and Garmaroudi, G. (2017) 'Predictors of intention to marriage based on theory of planned behavior among university students in Iran', Electronic Physician, Vol. 9, No. 4, pp.4090-4095. 
Sheppard, B.H., Hartwick, J. and Warshaw, P.R. (1988) 'The theory of reasoned action: a meta-analysis of past research with recommendations for modifications and future research', Journal of Consumer Research, Vol. 15, No. 3, pp.325-343.

Shinnar, R.S., Hsu, D.K. and Powell, B.C. (2014) 'Self-efficacy, entrepreneurial intentions and gender: assessing the impact of entrepreneurship education longitudinally', The International Journal of Management Education, Vol. 12, No. 3, pp.561-570.

Shrout, P.E. and Bolger, N. (2002) 'Mediation in experimental and nonexperimental studies: new procedures and recommendations', Psychological Methods, Vol. 7, No. 4, p.422.

Solomon, G. and Matlay, H. (2008) 'The impact of entrepreneurship education on entrepreneurial outcomes', Journal of Small Business and Enterprise Development, Vol. 15, No. 2, pp.382-396.

Souitaris, V., Zerbinati, S. and Al-Laham, A. (2007) 'Do entrepreneurship programmes raise entrepreneurial intention of science and engineering students? The effect of learning, inspiration and resources', Journal of Business Venturing, Vol. 22, No. 4, pp.566-591.

Stokes, D. and Wilson, N.C. (2010) 'Entrepreneurship and marketing education: time for the road less travelled?', International Journal of Entrepreneurship and Innovation Management, Vol. 11, No. 1, pp.95-108.

Tabachnick, B. and Fidell, L. (1996) 'Analysis of covariance', Using Multivariate Statistics, Vol. 8, No. 1, pp.321-374.

Tierney, P. and Farmer, S.M. (2002) 'Creative self-efficacy: its potential antecedents and relationship to creative performance', Academy of Management Journal, Vol. 45, No. 6, pp.1137-1148.

Tsang, S., Wang, W. and Ku, H. (2015) 'The intention of job seekers to apply for jobs in small and medium-sized coastal enterprises based on the theory of planned behavior', Journal of Coastal Research, Vol. 73, No. sp1, pp.665-675.

Van Gelderen, M., Brand M., van Praag, M., Bodewes, W., Poutsma, E. and Van Gils, A. (2008) 'Explaining entrepreneurial intentions by means of the theory of planned behaviour', Career Development International, Vol. 13, No. 6, pp.538-559.

Vázquez, J.L., Lanero, A., Gutierrez, P. and García, M.P. (2011) 'Fostering entrepreneurship at the university: a Spanish empirical study', Transylvanian Review of Administrative Sciences, Vol. 7, No. 32, pp.252-276.

Verduyn, K. and Jansen, P. (2005) 'Entrepreneurial myths. using biographies and (Ante) narrative research methods in entrepreneurship education', International Journal of Entrepreneurship Education, Vol. 3, No. 3, pp.229-244.

von Graevenitz, G., Harhoff, D. and Weber, R. (2010) 'The effects of entrepreneurship education', Journal of Economic Behavior and Organization, Vol. 76, No. 1, pp.90-112.

Walter, S.G. and Block, J.H. (2016) 'Outcomes of entrepreneurship education: an institutional perspective', Journal of Business Venturing, Vol. 31, No. 2, pp.216-233.

Weaver, M., Dickson, P. and Solomon, G. (2006) Entrepreneurship and Education: What is Known and Not Known about the Links between Education and Entrepreneurial Activity, The Small Business Economy: A Report to the President.

Wilson, F., Kickul, J. and Marlino, D. (2007) 'Gender, entrepreneurial self-efficacy and entrepreneurial career intentions: implications for entrepreneurship education', Entrepreneurship: Theory and Practice, Vol. 31, No. 3, pp.387-406.

Xinaris, C., Kourtellis, A., Kakouris, A. and Georgiadis, P. (2011) 'Game based learning in entrepreneurship: the academic business planner', Proceedings of The 5th European Conference on Games Based Learning, pp.650-656.

Zellweger, T., Sieger, P. and Halter, F. (2011) 'Should I stay or should I go? Career choice intentions of students with family business background', Journal of Business Venturing, Vol. 26, No. 5, pp.521-536. 
Zhao, H., Seibert, S.E. and Hills, G.E. (2005) 'The mediating role of self-efficacy in the development of entrepreneurial intentions', Journal of Applied Psychology, Vol. 90, No. 6, pp.1265-1272.

\section{Appendix}

Table 4 Items for success and failure stories

We would like to know what do remember of the videos. Which citations are from which entrepreneurs?

\begin{tabular}{|c|c|c|c|c|c|}
\hline Citations from success stories & Mean & $S D$ & Citations from failure stories & Mean & $S D$ \\
\hline $\begin{array}{l}\text { Important skills are goal } \\
\text { orientation, faith and perseverance }\end{array}$ & 0.09 & 0.285 & Quitting is failure & 0.06 & 0.235 \\
\hline $\begin{array}{l}\text { Never get started without a } \\
\text { mission! }\end{array}$ & 0.08 & 0.275 & $\begin{array}{l}\text { Always keep an eye on your cash } \\
\text { flow! }\end{array}$ & 0.07 & 0.252 \\
\hline $\begin{array}{l}\text { Define your own success } \\
\text { indicators! }\end{array}$ & 0.07 & 0.248 & There is no right or wrong decision. & 0.10 & 0.302 \\
\hline $\begin{array}{l}\text { Just do it - Live your dream! } \\
\text { Success is to do and make your } \\
\text { dreams come true }\end{array}$ & 0.09 & 0.292 & $\begin{array}{l}\text { You should always have an eye on } \\
\text { the market and have a diverse range } \\
\text { of products or service to find your } \\
\text { cash cows of tomorrow! }\end{array}$ & 0.12 & 0.328 \\
\hline $\begin{array}{l}\text { Get the real good customers and get } \\
\text { recognised by competitors. It is the } \\
\text { passion and the strong will to do } \\
\text { something besides talking to the } \\
\text { customers to feel their need }\end{array}$ & 0.08 & 0.278 & $\begin{array}{l}\text { Do not underestimate the power of } \\
\text { marketing! }\end{array}$ & 0.15 & 0.358 \\
\hline $\begin{array}{l}\text { It is all about the customer. Try to } \\
\text { grab the customer and learn with } \\
\text { him to develop your business }\end{array}$ & 0.12 & 0.322 & $\begin{array}{l}\text { Failures are part of the business - it } \\
\text { is a trial and error issue daily }\end{array}$ & 0.10 & 0.302 \\
\hline $\begin{array}{l}\text { Independence of my whole doing } \\
\text { was always important }\end{array}$ & 0.01 & 0.108 & $\begin{array}{l}\text { Maybe I have started my company } \\
\text { too early and too young }\end{array}$ & 0.01 & 0.084 \\
\hline $\begin{array}{l}\text { The good motivator is behind the } \\
\text { money }\end{array}$ & 0.01 & 0.108 & $\begin{array}{l}\text { The first years were really hard for } \\
\text { me }\end{array}$ & 0.01 & 0.118 \\
\hline $\begin{array}{l}\text { The most important is to be awake } \\
\text { and to think a lot }\end{array}$ & 0.01 & 0.097 & $\begin{array}{l}\text { To be an entrepreneur needs a lot of } \\
\text { time and a lot of energy }\end{array}$ & 0.02 & 0.144 \\
\hline $\begin{array}{l}\text { Independency and realising own } \\
\text { ideas are great reasons for starting } \\
\text { your business }\end{array}$ & 0.03 & 0.178 & $\begin{array}{l}\text { Keep your eyes open for new } \\
\text { entrepreneurial opportunities even it } \\
\text { is not easy to evaluate them. }\end{array}$ & 0.04 & 0.207 \\
\hline $\begin{array}{l}\text { Honesty is important for a long } \\
\text { term success }\end{array}$ & 0.04 & 0.201 & $\begin{array}{l}\text { It is important to evaluate the } \\
\text { resources for exploring and } \\
\text { exploiting entrepreneurial } \\
\text { opportunities }\end{array}$ & 0.04 & 0.185 \\
\hline $\begin{array}{l}\text { At the beginning it is important to } \\
\text { have a mission! }\end{array}$ & 0.04 & 0.201 & $\begin{array}{l}\text { It is important to have enough time } \\
\text { for your preparation before starting } \\
\text { the business }\end{array}$ & 0.04 & 0.207 \\
\hline $\begin{array}{l}\text { Einzigartiges Service und den } \\
\text { täglichen Überblick haben. Kunden } \\
\text { sollen kommen um zu bleiben }\end{array}$ & 0.10 & 0.302 & $\begin{array}{l}\text { Entscheidungen müssen getroffen } \\
\text { werden.... Immer auf die eigenen } \\
\text { Ressourcen achten }\end{array}$ & 0.09 & 0.292 \\
\hline
\end{tabular}


Table 4 Items for success and failure stories (continued)

We would like to know what do remember of the videos. Which citations are from which entrepreneurs?

\begin{tabular}{lcclll}
\hline Citations from success stories & Mean & SD & Citations from failure stories & Mean SD \\
\hline Gesundes Selbstbewusstsein ist & 0.11 & 0.311 & $\begin{array}{l}\text { Als Unternehmer bist du für alles } \\
\text { verantwortlich! Wenn es hart auf }\end{array}$ & 0.09 & 0.289 \\
essentiell & & & $\begin{array}{l}\text { hart geht, ist man als Unternehmer } \\
\text { der Letzte der überbleibt }\end{array}$
\end{tabular}

Immer mit offenen Augen und Ohren durch das Unternehmen und das Leben gehen um neue unternehmerischen Möglichkeiten zu erkennen

Mein Leben ist begeisterungsfähig, verantwortungsvoll und nachhaltig geworden. Mein privates Leben wurde zu $100 \%$ positiv beeinflusst

Selbst entscheiden was ich wann tue. Wenn man etwas für sich selbst macht, geht es schneller und besser zum Erfolg

Ich möchte authentisch bleiben und durch das entgegengebrachte Vertrauen Arbeitsplätze schaffen

It is always important to improve the technology in order to create local value and local jobs and to find new opportunities

The project is exciting. Meeting new people is great. You can enrich your life a lot with entrepreneurial activities

Success is to meet targets at $100 \%$
0.100 .302 Geht nicht, gibt es nicht. Es gibt immer einen Weg!

$0.11 \quad 0.317$ kein Wirtschaftsflüchtling werden und unterstützte die Bauern, die keinen Absatz hatten, da ich keine Arbeit hatte

$0.08 \quad 0.264$ Der Hauptgrund mich selbstständig $0.07 \quad 0.248$ zu machen war die fehlende

Wertschätzung als

Unselbstständiger

0.060 .244 Wichtig ist die Leute zu fragen, was $0.06 \quad 0.240$ sie eigentlich brauchen! Unsere

Kunden liefern uns Ideen und unsere zukünftigen Innovationen

$0.08 \quad 0.271$ A failure occurs when an unseen $\quad 0.08 \quad 0.268$ situation occurs

0.170 .375 When you have failed, you have to 0.150 .355 learn from them. You can learn a lot. Try to learn!

$0.13 \quad 0.336$ Analyse different business scenarios, include all different stakeholders and work with a good team to prevent mistakes

Table 5 Role model items

If you have an entrepreneurial role model, who is it?

\begin{tabular}{lcccc}
\hline $\begin{array}{l}\text { Items (scale: 1 = total disapproval....... } \\
\text { 7= total approval) }\end{array}$ & Mean & SD & $\begin{array}{c}\text { Item total } \\
\text { correlation }\end{array}$ & $\begin{array}{c}\text { Alpha if item } \\
\text { is deleted }\end{array}$ \\
\hline RM_1 Parents or siblings & 3.94 & 1.928 & 0.508 & 0.699 \\
RM_2 Friends & 3.96 & 1.706 & 0.693 & 0.587 \\
RM_3 Someone else who is important to me & 4.34 & 1.691 & 0.472 & 0.713 \\
$\quad \begin{array}{l}\text { and/or someone I do not know personally } \\
\text { RM_4 The entrepreneur from the video }\end{array}$ & 3.76 & 1.638 & 0.474 & 0.712 \\
\hline
\end{tabular}


Table 6 Self-efficacy items based on Chen et al. (2001) and Kickul et al. (2009)

Please indicate your level of agreement with the following statements!

\begin{tabular}{|c|c|c|c|c|}
\hline $\begin{array}{l}\text { Items (scale: } 1=\text { not confident; } 7=\text { completely } \\
\text { confident) }\end{array}$ & Mean & $S D$ & $\begin{array}{l}\text { Item total } \\
\text { correlation }\end{array}$ & $\begin{array}{l}\text { Alpha if item } \\
\text { is deleted }\end{array}$ \\
\hline \multicolumn{5}{|l|}{ Searching stage } \\
\hline $\begin{array}{l}\text { SE_S_1 Task 1: Conceive a unique idea for a } \\
\text { business }\end{array}$ & 1.595 & 1.595 & 0.934 & 0.934 \\
\hline $\begin{array}{l}\text { SE_S_2 Task 2: Identify market opportunities for } \\
\text { a new business }\end{array}$ & 1.492 & 1.492 & 0.929 & 0.929 \\
\hline \multicolumn{5}{|l|}{ Planning stage } \\
\hline SE_P_1 Task 3: Plan a new business & 1.545 & 1.545 & 0.928 & 0.928 \\
\hline SE_P_2 Task 4: Write a formal business plan & 1.577 & 1.577 & 0.932 & 0.932 \\
\hline \multicolumn{5}{|l|}{ Marshalling stage } \\
\hline SE_M_1 Task 5: Raise money to start a business & 1.593 & 1.593 & 0.932 & 0.932 \\
\hline $\begin{array}{l}\text { SE_M_2 Task 6: Convince others to invest in your } \\
\text { business }\end{array}$ & 1.543 & 1.543 & 0.930 & 0.930 \\
\hline $\begin{array}{l}\text { SE_M_3 Task 7: Convince a bank to lend you } \\
\text { money to start a business }\end{array}$ & 1.609 & 1.609 & 0.934 & 0.934 \\
\hline $\begin{array}{l}\text { SE_M_4 Task 8: Convince others to work for you } \\
\text { in your new business }\end{array}$ & 1.455 & 1.455 & 0.929 & 0.929 \\
\hline \multicolumn{5}{|l|}{ Implementing stage } \\
\hline SE_I_1 Task 9: Manage a small business & 1.511 & 1.511 & 0.932 & 0.932 \\
\hline SE_I_2 Task 10: Grow a successful business & 1.472 & 1.472 & 0.931 & 0.931 \\
\hline
\end{tabular}

Table 7 Perceived behavioural control based on Liñán and Chen (2009)

To what extent do you agree with the following statements regarding your entrepreneurial capacity?

\begin{tabular}{|c|c|c|c|c|}
\hline $\begin{array}{c}\text { Items (scale: } 1=\text { strongly disagree....... } \\
7=\text { strongly agree) }\end{array}$ & Mean & $S D$ & $\begin{array}{l}\text { Item total } \\
\text { correlation }\end{array}$ & $\begin{array}{c}\text { Alpha if item is } \\
\text { deleted }\end{array}$ \\
\hline $\begin{array}{l}\text { BC_1 } \begin{array}{l}\text { To start a firm and keep it working } \\
\text { would be easy for me }\end{array}\end{array}$ & 3.56 & 1.589 & 0.765 & 0.928 \\
\hline BC_2 I am prepared to start a viable firm & 3.54 & 1.645 & 0.830 & 0.920 \\
\hline $\begin{array}{l}\text { BC_3 I can control the creation process of a } \\
\text { new firm }\end{array}$ & 3.85 & 1.547 & 0.841 & 0.919 \\
\hline $\begin{array}{l}\text { BC_4 } \begin{array}{l}\text { I know the necessary practical details } \\
\text { to start a firm }\end{array}\end{array}$ & 3.51 & 1.606 & 0.822 & 0.921 \\
\hline $\begin{array}{l}\text { BC_5 I know how to develop an } \\
\text { entrepreneurial project }\end{array}$ & 3.51 & 1.627 & 0.837 & 0.919 \\
\hline $\begin{array}{l}\text { BC_6 If I tried to start a firm, I would have } \\
\text { a high probability of succeeding }\end{array}$ & 4.01 & 1.498 & 0.752 & 0.930 \\
\hline
\end{tabular}

